\title{
The Effect of Pilates Reformer Exercises to Tennis Skills on Tennis Players
}

\author{
Mine Gül \\ Correspondence: Mine Gül, Affiliation: Kocaeli University Sports Science Faculty, Umuttepe Campus, İzmit, Kocaeli, \\ Turkey.
}

Received: May 27, 2019

doi:10.11114/jets.v7i9.4294
Accepted: June 25, $2019 \quad$ Online Published: June 30, 2019

URL: https://doi.org/10.11114/jets.v7i9.4294

\begin{abstract}
The aim of this study is to determine the effect of reformer pilates trainings on ITN tennis test regarding the elite women aged 16-18 years. The research is done for voluntary participation of 14 elite female tennis players, whose age of training is $10,25 \pm 1,72$ years and average age 17,35 $\pm 0,77$ years, All athletes were tested on the first day, then they were randomly divided into control $(n=7)$ and experimental $(n=7)$ groups. 90 minutes of pilates training sessions were performed for 3 days/week during eight weeks. The experimental group applied the pilates reformer studies and participated in the team trainings of the control group. After the 8-weeks training program, the last measurements of ITN Skills test were taken from experimental\&control group athletes and the results were evaluated by SPSS 22.0 statistical program at 0.05 significance level. No significant difference was found for ITN depth\&strength test, vole test, service test and stellar test when the last measurement test parameters of the experimental\&control group athletes were compared $(\mathrm{p}>0.05)$. There was a significant difference between the two groups in the ITN sensitivity\&strength test analysis $(\mathrm{p}<0.05)$. As a result, it can be said that 8-weeks duration pilates reformer trainings have an effect on the tennis players' ability to reach the ball on time in parallel and cross-strokes and an effect to have a recovery ability to be ready for the next shot.
\end{abstract}

Keywords: tennis, pilates, ITN tennis tests

\section{Introduction}

In the Pilates method, which targets the training of muscles, the exercises start with a light but equally demanding structure. In case the athlete applies the movements by stabilizing the body, more difficult movements could be passed. It is quite important that instructors who will present pilates exercises have many skills and become experts in this field (İnan et al., 2018). Joseph Humbertus Pilates, formed his philosophy on physical fitness base, inspiring from the eastern\&western philosophies, combined yoga's mental focus and special breathing techniques, gymnastics and other sports with the physical skills; has taken base of combination with biomechanics, motor learning and core stabilization theories (Katayıfçı, 2014). Pilates improves flexibility, strength\&endurance, improves posture, improves quality of life and improves quality of life by slowing down aging. Pilates exercises are recommended to be more functional and active in daily activities, to have elastic muscle mass and flexible backbone and to improve cardiac respiration resistance, muscular resistance, muscle force, muscle strength, speed, flexibility, agility, balance and improving reaction time (Aslan, 1997). Pilates is a uniquie form of therapeutic exercise method emphasizing strength, coordination, proprioception, muscle resistance, balance and control, flexibility and mobility, exercise that helps prevent injury. Therefore, by incorporating Pilates into a rehabilitation program, healing period is significantly improved (Cozen, 2000; Chinnavan, 2015; Segal et al., 2004; Jago et al., 2006). Performance improvement can be provided by planning exercises in the light of training science in sportive branch power, flexibility, balance, coordination and timing in technical skills and developing branch-specific reaction skills. In this study, in the light of literature research, it was aimed to determine the effect of pilates exercises by using reformer tool on ITN tennis skills of tennis players.

\section{Materials and Methods}

\subsection{Research Group}

Women tennis players who play in Istanbul Yeşilyurt Tennis Club between the ages of 16-18 are randomly divided into two groups consisting of 7 people, experimental\&control groups (total $n=14$ ) were formed. The first measurement data analysis detected that the groups were homogeneous. Experimental group athletes' ages are $17.0 \pm 0.75$ years, training ages $10.14 \pm 2.16$ years, height is $169.57 \pm 1.84 \mathrm{~cm}$ and body weights $66.24 \pm 1.69 \mathrm{~kg}$. The age of the control group 
athletes was $16.71 \pm 0.69$ years, the training ages were $10.42 \pm 1.49$ years, the heights were $168.14 \pm 2.41 \mathrm{~cm}$ and the body weight was $64.21 \pm 2.92 \mathrm{~kg}$.

\subsection{Training Procedure}

This study was adapted for 8 weeks, 3 days per week, and 90 minutes for unit training period. Experimental group performed 90-minute training pilates with reformer work as 10-15 repetitions\& 45 second rest between repetitions, 3 to 5 sets and rests between the sets were determined to be 1 minute; they continued tennis training after the studio work. The control group athletes were continued their team training.

Table 1. Training Procedure table

\begin{tabular}{|c|c|c|}
\hline \multicolumn{3}{|c|}{ MOVEMENTS } \\
\hline 1 & Double Leg Press (Plantar Flexion-Paralel) & 11 Rhomboid Squeeze \\
\hline 2 & Double Leg Press (Dorsiflexion-Paralel) & Biceps Curl \\
\hline 3 & Calf Raise & Triceps Extencion \\
\hline 4 & Abdominal Crunch & Seated Row \\
\hline 5 & Single Leg Kick -Triceps Pres & Chest Fly \\
\hline 6 & Froggie & The Gift \\
\hline 7 & Bridge & The Half Swan \\
\hline 8 & Standing Abduction & Shoulder Pres \\
\hline 9 & Leg Circle & Lunge Stretch \\
\hline 10 & Froggie Circle & 20 The Elephant Stretch \\
\hline & WEEKS & Repeat*Sets*Time (dk) \\
\hline & $1-2$ Weeks & $10 * 3 * 40$ \\
\hline & 3 - 4 Weeks & $10 * 4 * 40$ \\
\hline & $5-6$ Weeks & $15 * 5 * 40$ \\
\hline & $7-8$ Weeks & $15 * 6 * 40$ \\
\hline
\end{tabular}

\subsection{ITN Tennis Test (International Tennis Number Test)}

ITN trains athletes who play professional tennis all over the world in order to be able to win matches\&show maximum performance in international sports events. The tennis players won points for the matches they have won throughout the year, they gain status in national and international level. In order to evaluate yearly performance of coaches and athletes, by this application, which was started by the ITF in order to evaluate the yearly performance levels of coaches and athletes, instead of technical strokes of the athletes, including five game situations, the service shot, the deep (long) strokes shot in the bottom line and the continuity applied to the vole strokes while was close to the net, deep strokes and physical mobility skills are examined. The general score is calculated by summing the scores according to the area where the balls fall (4-3-2-1 points), the score taken by crashing the area called the power field after the bounce ( 2 points) and (+1 score) from each approved ball (Fig.1).

Ground-Shots Depth and Power Test; The score is calculated by the number of 10 balls 10 (Forehand-Backhand) crashed to player standing on the back line of tennis court and it is recorded. (Sportsman takes maximum 90 points from this section (10x4x2+10) (Fig.2).

Ground stroke sensitivity and power test; The score is calculated as below: On the tennis court, the 6 ball to parallel (Forehand-Backhand) and the 6-ball to cross court (Forehand-Backhand) shot to player standing on the back line are scored again according to the region of the deepest chase. (The athlete receives a maximum of 84 points $(12 \times 3 \times 2+12)($ Fig.3).

Vole strokes depth and power test; Tries to gain higher scores by shoting 8 balls (Forehand-Backhand) to the player who is standing at the midpoint of the service line on the tennis court (T zone), again by throwing balls near the bottom line of the opposing court. The athlete will receive a maximum of 72 points $(8 \times 4 \times 2+8)($ Fig.2).

Service strokes test; The tennis player stops serving the bottom line near the center line. The athlete is asked to provide 12 service shots. Each cross service box is divided into two zones. 3 ball is asked to throw to the first zone, 3 to the second zone from the right. It uses other balls in the same way. (The athlete has a maximum of 108 points to be collected from this section $(12 \times 4 \times 2+12)$ (Fig.4).

Mobility Test (Speed Test); In this test, a player is asked to collect five tennis balls placed in different parts of the cord one by one and to bring the racket (to the area-material) in the center line as soon as possible and the time is recorded (Fig.5) (Gül et al., 2017).

\subsection{Statistical Analyses}


At the end of the 8-weeks training program, the data obtained by taking the final measurements of ITN Tennis Skills test were analyzed on the computer by means of SPSS 22.0 statistical software program. As a result of the data analysis of the athletes, due to inconveniency to normal distribution, Wilcoxon test analysis which is one of the nonparametric test measurements was performed in-group and Man-Withney $U$ test analysis was performed inter-group.

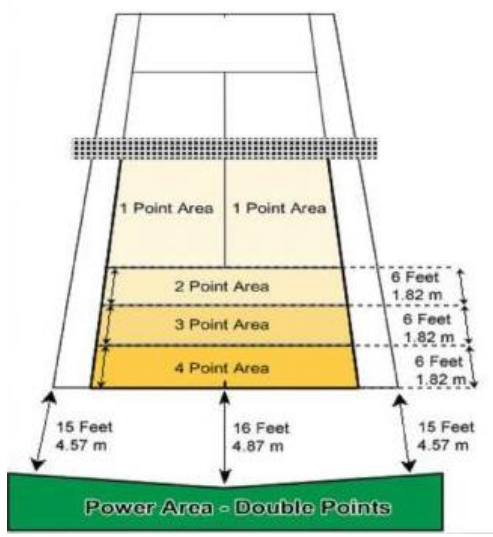

Figure 1. ITN Tennis Court And Scoring

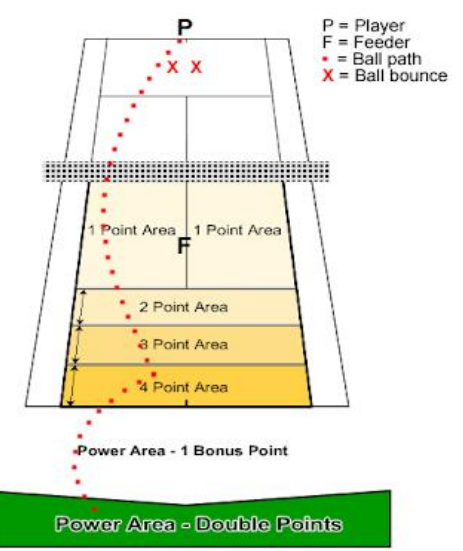

Figure 2. ITN Ground Stroke And Volley Depth and Power Tests

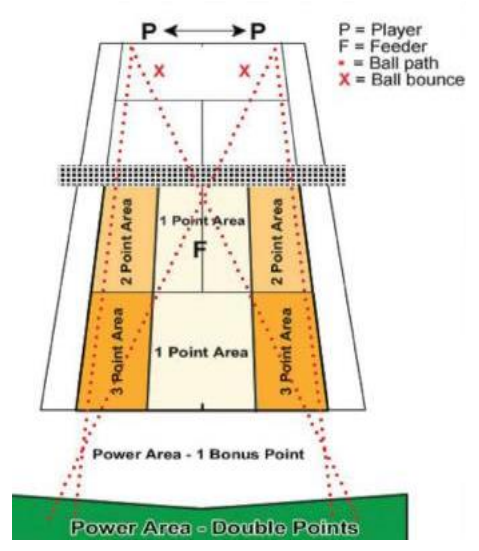

Figure 3. ITN Ground Stroke And Sensivity Tests 


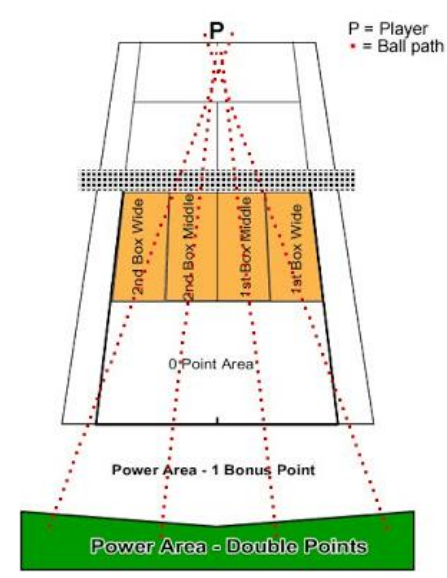

Figure 4. ITN Service Tests

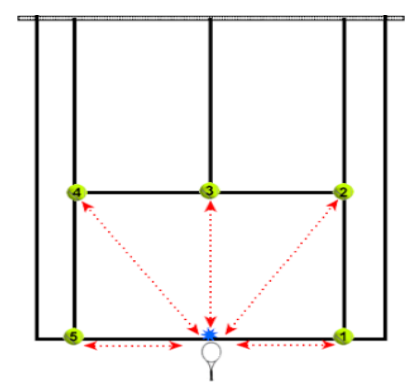

Figure 5. ITN Mobility Tests (Ttf. Org.Tr.2018)

\section{Results}

Table 2. Descriptive Statistics and First-Last Measurement Analysis Table Of Control And Experimental Group

\begin{tabular}{|c|c|c|c|c|c|c|c|c|c|c|}
\hline & \multirow{2}{*}{$\mathbf{N}$} & \multirow{2}{*}{ TESTS } & \multicolumn{4}{|c|}{ CONTROL GROUP $(\mathrm{n}=7)$} & \multicolumn{4}{|c|}{ EXPERIMENTAL GROUP $(\mathrm{n}=7)$} \\
\hline & & & $\mathrm{X} \pm \mathrm{Ss}$ & Difference & $\mathbf{Z}$ & $\mathbf{P}$ & $\mathrm{X} \pm \mathrm{Ss}$ & Difference & $\mathbf{Z}$ & $\mathbf{P}$ \\
\hline AGE (year) & 14 & & $16,71 \pm 0,75$ & & & & $17 \pm 0,81$ & & & \\
\hline TRAINING AGE (year) & 14 & & $10,42 \pm 1,61$ & & & & $10,14 \pm 2,34$ & & & \\
\hline HEIGHT (cm) & 14 & & $168,14 \pm 2,60$ & & & & $169,57 \pm 1,98$ & & & \\
\hline WEIGHT (kg) & 14 & & $64,21 \pm 3,16$ & & & & $66,24 \pm 1,83$ & & & \\
\hline ITN DEPTH AND & 14 & FIRST TEST & $79,86 \pm 3,58$ & 272 & -1612 & 0107 & $80,43 \pm 3,46$ & $243+2>>3$ & -1527 & 0127 \\
\hline POWER TESTS (point) & 14 & LAST TEST & $82,57 \pm 1,99$ & & $-1,612$ & $0,10 /$ & $82,86 \pm 2,41$ & & $-1,527$ & 0,121 \\
\hline ITN SENSIVITY AND & 14 & FIRST TEST & $70,43 \pm 1,99$ & -1.29 & -1.16 & 0.246 & $72,00 \pm 2,58$ & 2.43 & -1.876 & 0.061 \\
\hline POWER (point) & 14 & LAST TEST & $69,14 \pm 2,19$ & $-1,29$ & $-1,16$ & 0,246 & $74,43 \pm 1,99$ & 2,43 & $-1,8 / 6$ & 0,061 \\
\hline ITN VOLE (point) & $\begin{array}{l}14 \\
14\end{array}$ & $\begin{array}{l}\text { FIRST TEST } \\
\text { LAST TEST }\end{array}$ & $\begin{array}{l}61,86 \pm 4,60 \\
6386+1,35\end{array}$ & 2 & $-0,847$ & 0,397 & $\begin{array}{l}66,00 \pm 3,74 \\
66,43+3,31\end{array}$ & 0,43 & $-0,172$ & 0,863 \\
\hline ITN SFRVICF (noint) & 14 & FIRST TEST & $83,57 \pm 5,97$ & & & & $85,71 \pm 5,65$ & & & \\
\hline ITN SERVICE (point) & 14 & LAST TEST & $84,14 \pm 4,63$ & 0,57 & & 46 & $85,14 \pm 6,28$ & $-0,57$ & 56 & ,798 \\
\hline ITN MOBILITY (point) & $\begin{array}{l}14 \\
14\end{array}$ & $\begin{array}{l}\text { FIRST TEST } \\
\text { LAST TEST }\end{array}$ & $\begin{array}{l}48,86 \pm 9,39 \\
46,14+4,56\end{array}$ & $-2,72$ & $-0,68$ & 0,497 & $\begin{array}{l}45,57 \pm 9,20 \\
50,43 \pm 6,85\end{array}$ & 4,86 & $-0,843$ & 0,399 \\
\hline
\end{tabular}

Wilcoxon Signed Ranks test results between pre- and post-values in a group

As shown in Table 2, there was no statistically significant difference between the control and experimental groups, on ITN depth and power, sensitivity, vole, service\&star test -within group- in the first-end data analysis results ( $p>0.05$ ). In ITN depth measurements, the difference between the first and last measurement averages of control group increased by +2.72 points and the experimental group increased by +2.43 points. The ITN Sensitivity test experimental group was aware of the averages of +2.43 points, while the ITN mobility test experimental group was aware of the averages increased by +4.86 points. 
Table 3. Final Measurement Analysis Table of the Experimental and Control Group

\begin{tabular}{|c|c|c|c|c|c|c|c|}
\hline & $\mathbf{N}$ & TEST & $\begin{array}{c}\text { CONTROL } \\
(\mathbf{n}=7)\end{array}$ & $\begin{array}{c}\text { EXPERIMENTAL } \\
(n=7)\end{array}$ & & & \\
\hline & & & $\mathrm{X} \pm \mathrm{Ss}$ & $\mathrm{X} \pm \mathrm{Ss}$ & Difference & $\mathbf{Z}$ & $\mathbf{P}$ \\
\hline $\begin{array}{l}\text { ITN DEPTH AND POWER } \\
\text { (point) }\end{array}$ & 14 & $\begin{array}{c}\text { LAST } \\
\text { TESTS }\end{array}$ & $82,57 \pm 1,99$ & $82,86 \pm 2,41$ & 0,29 & $-0,646$ & 0,518 \\
\hline $\begin{array}{c}\text { ITN SENSIVITY AND POWER } \\
\text { (point) }\end{array}$ & 14 & $\begin{array}{l}\text { LAST } \\
\text { TESTS }\end{array}$ & $69,14 \pm 2,19$ & $74,43 \pm 1,99$ & 5,29 & $-3,019$ & $\mathbf{0 , 0 0 3} *$ \\
\hline ITN VOLE (point) & 14 & $\begin{array}{l}\text { LAST } \\
\text { TESTS }\end{array}$ & $63,86 \pm 1,35$ & $66,43 \pm 3,31$ & 2,57 & $-1,685$ & 0,092 \\
\hline ITN SERVICE (point) & 14 & $\begin{array}{l}\text { LAST } \\
\text { TESTS }\end{array}$ & $84,14 \pm 4,63$ & $85,14 \pm 6,28$ & 1 & $-0,129$ & 0,897 \\
\hline ITN MOBILITY (point) & 14 & $\begin{array}{c}\text { LAST } \\
\text { TESTS }\end{array}$ & $46,14 \pm 4,56$ & $50,43 \pm 6,85$ & 4,29 & $-1,364$ & 0,172 \\
\hline
\end{tabular}

Mann-Whitney U-test results between pre and post values in both groups*(p<0,05)

As shown in Table 3, a statistically significant difference was found in favor of the experimental group in the ITN Sensitivity test control and experimental group final measurement analysis (the average last measurement difference is +5.29 points in favor of experimental group) $(\mathrm{p}=0.003)$. Although there was no statistically significant difference between the measurements ( $p>0.05$ ), when the average difference is analyzed; it was found to be increased in favor of the experimental group.

\section{Discussion}

In the study, the effect of pilates reformer exercises applied to tennis athletes by field tennis test was investigated. Tennis is a dynamic sports branch, by which strength, agility, speed, coordination, reaction, balance and flexibility characteristics are fully applied, the results of training activity is obtained and the performance of the match is improved (Munivrana, et al., 2015).

When the findings of the study are examined, it is necessary to have the power to put the ball back into the bottom line because the score is recorded according to the points taken from the balls that are thrown to the bottom line of ITN depth strokes tennis cord. The first measurement in the control group was 79,86 $\pm 3,58$ and the final mean score of $82,57 \pm 1,99$ points was found in the ITN depth test for the effect of pilates exercises on tennis skills. In the experimental group, the mean of the first measurement was $80.43 \pm 3.46$ and the mean of the last measurement was $82.86 \pm 2.41$. There was an increase in mean values of intra-group analysis results but no statistically significant $(\mathrm{p}>$ 0.05). ITN Sensitivity strokes, points are scored by throwing the balls to the parallel and the diagonal. The athlete is asked to make an early balance by hitting the couples corridor until they are reacting to these balls earlier and coming to the stroke position. In the ITN sensitivity test, the mean first measurement in the control group was $70.43 \pm 1.99$ and the final mean score was $69.14 \pm 2.19$. In the experimental group, the mean of the first measurement was $72.00 \pm 2.58$ and the last measurement average was $73.43 \pm 1.99$ points. There was no significant difference in intragroup analysis ( $\mathrm{p}>$ 0.05), but an increase in experimental group mean values was found. ITN Vole strokes, the athlete's service line (T line) is asked to throw strokes into the bottom line. Since the athlete has centered the cord and stands closer to the net, he must strike by the reaction and full rotation and throw the ball to the highest score on the bottom line with weight transfer. The mean ITN vole test was $61,86 \pm 4,60$ in the control group and $63,86 \pm 1,35$ points in the last measurement. In the experimental group, the mean of the first measurement was $66,00 \pm 3,74$ and the mean of the last measurement was $66,43 \pm 3,31$ points. No statistical difference was found in intragroup analysis ( $p>0.05$ ). ITN Service strokes, offense strokes in the skill. The athlete's ball and racket to meet the harmony of the full technical and force application of the match with the kick kick applied. In the ITN service test, the first measurement in the control group was found to be $83.57 \pm 5$, and the last measurement average was $84.14 \pm 4.63$ points. In the experimental group, the mean of the first measurement was $85,71 \pm 5,65$ and the average of the last measurement was $85,14 \pm 6,28$ points. No statistical difference was found in intragroup analysis ( $p>0.05$ ). ITN Star test is an application that measures the fastness skills of tennis athletes. It is such a test that the balls are released which are placed in 5 points in a tennis racket on the center line of the tennis cord. The time is scored. According to ITN star test results, the mean of first measurement was 
detected as 48,86 $\pm 9,39$ in the control group and the mean of the last measurement was detected as $46,14 \pm 4,56$ seconds. In the experimental group, the mean of the first measurement was detected as $45.57 \pm 9.20$ and the final measurement was detected as $50.43 \pm 6.85 \mathrm{sec}$. No statistical difference was found in intragroup analysis ( $\mathrm{p}>0.05$ ). As a result of the last measurement analysis of the athletes, the average of the control group was $69.14 \pm 2.19$ and the mean of the experimental group was $74.43 \pm 1.99$ and a significant difference was found $(p=0.003)$. It was concluded that the pilates reformer exercises applied to the training group had an effect on parallel and cross-strokes.

As a result of the literature research, it was found out that clinical, reformer pilates exercises had an effect on flexibility values during the training period (Chinnavan et al., 2015; Baştuğ et al., 2014; Aslanoğlu and Şenel, 2013; Demir and Çilli, 2018; Rogers and Gibson, 2009; Karadenizli and Kamur, 2016; Katayıfçı et al., 2014), BMI (Body mass index) is effective in the values (Baştuğ et al., 2014; Abramaviči et al., 2013; Jago et al., 2006), decreased body fat percentage values (Aslanoğlu and Şenel, 2013; Abramavičiūtč et al., 2013; Sekendiz et al., 2006; Jago et al., 2006), which are effective in muscle strength parameters (Aslanoğlu and Şenel, 2013; Abramavičiūtč et al., 2013; Sekendiz et al., 2006; Rogers and Gibson, 2009; Katayıfçi et al., 2014), the physical fitness parameters of the environment, skin fold measurement, waist hip ratio, body composition values are effective on (Rogers and Gibson, 2009; Katayıfçı et al., 2014 ; Liman and Güzel, 2008; Gökçelik, 2017) and the Pilates exercise to be effective in physiological parameters (Liman and Güzel, 2008; Temur et al., 2018), has also been found to be effective on balance performance (Katayıfçı et al., 2014; Demir and Çilli, 2018; Atılgan et al., 2016).

As a result of the studies, it can be said that pilates exercises have a positive effect on technical performance (Demir and Çilli, 2018) and that pilates exercises have an effect on tennis skills. It has been concluded that equilibrium enhancing skills have an effect on tennis performance (Ertem et al., 2012), and that special strength training and flexibility studies can improve tennis skills (Gül et al., 2017). The aim of this study was to investigate the performance of pilates exercises in tennis. In the light of the results, it can be thought that the significance gained in pilates exercises in terms of flexibility, strength, balance and focus on strokes. As a result, the 8-week pilates reformer trainings are considered to have an effect on the tennis players' ability to reach the ball in parallel and cross-strokes in time and to be able to recover in order to be ready for the next shot.

\section{Acknowledgements}

We are very grateful to Simge Bingöl and Gazanfer Kemal Gül for their help and support in the practice of this study and in the literature research.

\section{References}

Abramavičiūtè, V., Zaičenkovienè, K., \& Sujeta, A. (2013). The influence of pilates exercıse on women's anthrophometry indıces, core muscle performance and heart rate changes durıng the session. Ugdymas Küno Kultūra Sportas. Nr. 2(89), 5-11. https://doi.org/10.33607/bjshs.v2i89.153

Aslan, S. H., Alpaslan, R. O., \& Ünal, M. (1997). A comparative study of body image satisfaction, depression, and anxiety in adolescents doing sports, 5th National Sports Medicine Congress Abstracts, 19-100, Ankara.

Aslanoğlu, E., \& Şenel, Ö. (2013). Effects of pilates training on some physiological parameters and cardiovascular risk factors of middle aged sedentary women. International Journal of Sport Studies. 3(2), 122-129.

Atılgan, E., Polat, B., \& Ataç, A. (2016). The effect of yoga-pilates program on balance in healthy women: pilot study. II. National Health Sciences Congress, November 24-25. HU Journal of Faculty of Health Sciences, 3, 1.

Baştuğ, G., Ceylan, H.I., \& Kalfa, S. (2014). The effect of pilates exercise program on flexibility performance and body composition.International Journal Of Human Sciences, 11(2), 1274-1286. https://doi.org/10.14687/ijhs.v11i2.3093

Chinnavan, E., Gopaladhas, S., \& Kaikondan, P. (2015). Effectiveness of pilates training in improving hamstring flexibility of football players. Bangladesh Journal of Medical Science 14(03), 265-269.

https://doi.org/10.3329/bjms.v14i3.16322

Cozen, D. M. (2000). Use of pilates in foot and ankle rehabilitation. Sports Medicine and Arthroscopy Revlew, 8(4), 395-403. https://doi.org/10.1097/00132585-200008040-00011

Demir, C. I., \& Çilli, M. (2018). Investigation of the effects of 12-week pilates mat exercise on some biomotor characteristics and technical performance of 14-15 year old volleyball female students. Online Turkish Journal of Health Sciences, 3(1), 1-13. https://doi.org/10.26453/otjhs.364026

Ertem, E., Gül, M., \& Gül, G. K. (2012). The effect of coordination trainings on 10-12 years lady tennis players on dewitt-dugan and wall catch tennis tests. http://akademikpersonel.kocaeli.edu.tr/minegul/poster/minegul25.12.2013_10.09.31poster.pdf 
Gökçelik, E. (2017). The effect of pilates exercises applied to university students on body composition and some motoric properties. T. C. Bartın University, Academic Archive. http://acikerisim.bartin.edu.tr:8080/xmlui/handle/11772/328

Gül, M., Bulut, Z., \& Gül, G. K. (2017). The effect of strength training on tennis skills. Journal of Physical Education and Sports Research, 9(1), 44-50.

İnan, M., Özden, B., Bal, M., Erdem, S., Yurtbaşı, Ö., Yüce, İ., \& Keskin, K. (2018). A Need Analyses For Pilates Educational Training. Journal of Physical Education and Sports Studies (JPESS), 10(1), https://doi.org/10.30655/besad.2018.5

Jago, R., Jonker, M., Missaghian, M., \& Baranowski, T. (2006). Effect of 4 weeks of pilates on the body composition of young girls. Preventive Medicine,42, 177-180. https://doi.org/10.1016/j.ypmed.2005.11.010

Karadenizli, Z. I., \& Kambur, B. (2016). The effect of Pilates reformer exercises on thigh circumference and hamstring flexibility in sedentary women. Inonu University, Journal of Physical Education and Sports Sciences, 3(3), 48-62.

Katayıfçı, N., Düger, T., \& Ünal, E. (2014). The effect of clinical pilates exercises on physical fitness in healthy individuals. Journal of Exercise Therapy and Rehabilitation, 1(1), 17-25.

Liman, N., \& Güzel, N. A. (2008). Effects of aerobic step and pilates exercises on strength, flexibility, anaerobic power, balance and body composition. Gazi Journal of Physical Education and Sport Sciences (gazi besbd), XIII(4), 3-12.

Munivrana, G., Flipcic, A., \& Filipcic, T. (2015). Relationship of speed, agility, neuromuscular power, and selected anthropometrical variables and performance results of male and female junior tennis players. Collegium antropologicum, 39(1), 109-116.

Rogers, K., \& Gibson, A. L. (2009). Eight-week traditional mat pilates trainingprogram effects on adult fitness characteristics. Research Quarterly For Exercise and Sport, Physical Education, Recreation and Dance, 80(3), 569574. https://doi.org/10.1080/02701367.2009.10599595

Segal, N. A., Hein, J., \& Basford, J. R. (2004). The effects of pilates training on flexibility and body composition: an observational study. Arch Phys Medical Rehabilitation, (85), 77-81. https://doi.org/10.1016/j.apmr.2004.01.036

Sekendiz, B., Altun, Ö., Korkusuz, F., \& Akın, S. (2006). Effects of .pilates exercise on trunk strenght, endurance and flexibility in sedantery adult females. Journal of Bodywork and Movement Therapies. 11, 318-326. https://doi.org/10.1016/j.jbmt.2006.12.002

Temur, H. B., Selçuk, M., Çınar, V., Öztürker, M., \& Sarıkaya, M. (2018). The effects of 8-week pilates program on blood lipids in women. Gaziantep University Journal of Sport Sciences, 3(1), 99-106.

Ttf.org.tr. (2016). ITN Tennis Test. (ttf.org.tr/wp-content/uploads/itn testi.doc). (11.06.2016).

\section{Copyrights}

Copyright for this article is retained by the author(s), with first publication rights granted to the journal.

This is an open-access article distributed under the terms and conditions of the Creative Commons Attribution license which permits unrestricted use, distribution, and reproduction in any medium, provided the original work is properly cited. 